\title{
Editorial: HIV and Cancer Immunotherapy: Similar Challenges and Converging Approaches
}

\author{
Mirko Paiardini ${ }^{1,2 *}$, Kavita Dhodapkar ${ }^{3}$, Justin Harper ${ }^{1}$, Steven G. Deeks ${ }^{4}$ and Rafi Ahmed ${ }^{5}$ \\ 1 Division of Microbiology and Immunology, Yerkes National Primate Research Center, Emory University, Atlanta, GA, \\ United States, ${ }^{2}$ Department of Pathology and Laboratory Medicine, Emory University School of Medicine, Atlanta, GA, \\ United States, ${ }^{3}$ Department of Pediatrics, Emory University School of Medicine and Children's Healthcare of Atlanta, Atlanta, \\ GA, United States, ${ }^{4}$ Division of Experimental Medicine, University of California, San Francisco, San Francisco, CA, \\ United States, ${ }^{5}$ Emory Vaccine Center and Department of Microbiology and Immunology, Emory University School of \\ Medicine, Atlanta, GA, United States
}

Keywords: HIV, cancer, ART, immunotherapy, immune surveillance, immune checkpoint blockade, inflammation, CAR T cells

\section{Editorial on the Research Topic}

\section{HIV and Cancer Immunotherapy: Similar Challenges and Converging Approaches}

\section{INTRODUCTION}

Although modern anti-retroviral therapy (ART) permits near-normal life expectancies by suppressing viral replication to clinically undetectable levels in people living with HIV (PLWH) (1), sustained treatment is complicated by complex pharmacological (i.e., adverse events, adherence, resistance) and societal issues (i.e., stigma, cost burden, medical access). Furthermore, ART is incapable of eliminating the latent viral reservoir, which is responsible for recrudescence when therapy is interrupted (2-5). Viral persistence is facilitated by a variety of mechanisms such as the exhaustion of HIV-specific cytolytic T-cells (CTLs) driven by chronic inflammation (6-8); epigenetic modifications to dampen the expression of viral proteins allowing evasion of immunosurveillance $(9,10)$; the localization of infected cells within immune privileged anatomical sites (11-13); and the survival of long-lived, virus-harboring cells allowing reservoir expansion via homeostatic proliferation $(14,15)$. Although formidable challenges exist for completing eradicating HIV from infected individuals (a "cure"), there is growing enthusiasm that novel immunotherapy approaches might eventually result in durable control of replication-competent HIV in absence of any therapy (a "remission"). Much of this enthusiasm comes from dramatic progress made in using immunotherapy to treating cancer. This editorial summarizes how the 13 review articles included in this special issue highlight key parallels between HIV and tumor persistence as well as how these similarities inform the development of novel immunotherapy-based strategies toward an HIV cure.

\section{THE PERSISTENCE OF MEMORY}

In both HIV and cancer, subsequent pathology arises from a relatively rare, yet difficult to distinguish and persistent subset of cells. In the non-human primate model of HIV infection, the persistent viral reservoir is established within 4-9 days post-infection (16); similarly, very early ART initiation does not induce viral remission in PLWH (17). In a meta-analysis of human cohorts, Etemad et al. propose that preferential infection of transitional memory $\left(\mathrm{T}_{\mathrm{TM}}\right)$ $\mathrm{CD}^{+}{ }^{+}$T-cells, as opposed to longer-lived central memory or naïve cells, is a key predictor for 
post-treatment control (18) despite weak HIV-specific CD8 ${ }^{+}$ T-cell responses. Intriguingly, Goonetilleke et al. hypothesize that the generation of the long-lived reservoir, particularly in central memory $\left(\mathrm{T}_{\mathrm{CM}}\right)$ and stem-cell memory $\left(\mathrm{T}_{\mathrm{SCM}}\right) \mathrm{CD}^{+}$ T-cells, can be blunted by inhibiting the IL-7 signaling axis, thereby disrupting the transition and maintenance of $\mathrm{CD} 127^{+}$ memory subsets from highly-infected effector CD $4^{+}$T-cells (18). Gavegnano et al. explore the use of Jak inhibitors in inhibiting the activity of the anti-apoptotic Bcl-2 protein to reduce cellular lifespans $(19,20)$. By blocking the formation and maintenance of the viral reservoir in long-lived memory subsets, the authors proposed that a reduction in viral burden will facilitate HIV remission as mimicked in post-treatment controllers.

\section{ESCAPE THROUGH EDITING}

Once the viral reservoir is established, HIV-specific $\mathrm{CD}^{+}{ }^{+} \mathrm{T}$ cells are required for viral suppression $(21,22)$; however, in most infected people, HIV-specific CTLs are incapable of eliminating infected cells (23) indicative of failure in immune surveillance independent of mutational escape or dysfunction (24). This incomplete elimination permits subsequent equilibrium phase sculpting of reservoir-harboring cells by immune pressures, which in cancer models has been termed "immunoediting" (25). Analogous to "antigen loss" in tumors models, Huang et al. explore the novel concept that during ART cells harboring replication-competent virus undergo clonal expansion with subsequent immunoediting; thereby decreasing CTL susceptibility by selecting for BCL-2 expression (26) and integration sites favoring cell division $(27,28)$. As HIV infection impacts on cellular metabolism and oxidative stress $(29,30)$, immunoediting may also select for an altered cellular lipid antigen composition that, as summarized by Tiwary et al., in oncology models impinges on chronic inflammation by modulating the macrophage M1 to M2 balance (31) and impairs antigen processing in dendritic cells (32); specifically, CD1d antigen loading for natural killer T-cells (NKT) (33). As a model comparison (Mota and Jones) examine how HTLV-1 generates malignant "repliclones" by an interplay of host- and viralmediated immunoediting. Therefore, these articles support the notion that HIV CTL escape might be more complex than viral epitope mutations, but rather involve the progressive selection of immunoedited, infected cells resistant to immune surveillance.

\section{WHO WATCHES THE WATCHMEN?}

Effective immunosurveillance of HIV-infected cells remains problematic as CTLs exhibit exhausted effector functions arising from chronic inflammation and antigen persistence during the natural course of infection and residual inflammation, driven by microbial translocation in the gut, despite suppressive ART $(34,35)$. Structural defects in gut integrity cause by HIV further impacts the microbiota distribution (36), which given its ability in cancer models to modulate toxicity (37) and therapy efficacy $(38,39)$, may represent an attractive therapeutic avenue as proposed by Herrera et al.. In some respects, as describe by
Dhodapkar and Dhodapkar, ART-suppressed HIV mirrors preclinical malignancy, a prolonged state characterized by earlyonset of T-cell exhaustion coupled with the depletion of stem cell memory (40). However, unlike antigen-rich tumor models, curative HIV therapies require that latent virus be reactivated to render infected cells immunogenic and cleared by potent anti-HIV CTLs ("kick and kill”) (10,41). Given their capacity to promote tumor clearance, as detailed by Puronen et al., many immunotherapies are being investigated in HIV cure studies to induce T-cell activation and restore CTL functionality, such anti-PD-1 and anti-CTLA-4 check point inhibitors (CPI) (42-44), and IL-7 and IL-15 cytokine therapy (45, 46). Given emerging data concerning the importance of innate natural killer (NK) cells in the control of HIV and cancers $(47,48)$, Lucar et al., discuss immunotherapies targeting NKG2a and killercell immunoglobulin-like receptors (KIRs) as novel strategies to determine whether dysfunction NK cell states can be rescued. Curative strategies centered around CPIs have revolutionized the treatment of certain refractory cancers by reinvigorating the host immune response; yet, in PWLH it remains to be seen whether antigen burden is a critical determinant of response.

\section{IN CASE OF EMERGENCY-BREAK GLASS}

Beyond these strategies, which may above prove too toxic, fail to penetrate tissue, or lack desire specificity, alternative curative approaches utilize adoptive T-cell therapy to redirect CTL responses. Kim et al. describe the re-emergence of chimeric antigen receptor (CAR) T-cells as an attractive immunotherapy strategy given its progressive re-engineering in oncology settings to improve safety, expression, and persistence (49). Although CAR T-cells have attained remarkable remission rates for $\mathrm{CD}^{+}{ }^{+}$B-cell acute lymphoblastic leukemia (50), significant relapse rates are associated with diminished persistence upon antigen loss/escape, the suppressive tumor microenvironment, and impaired tumor penetration (51). These issue impacting tumor relapse are directly analogous to HIV models vis-ávis ART-mediated aviremia, the expansion of regulatory T-cells ( $\left.\mathrm{T}_{\text {REGs }}\right)(52,53)$, and the exclusion of CTLs from secondary lymphoid tissue $(13,54)$. Possible strategies to surmount these issues include engineering CAR T-cells to express 4-1BB costimulatory domains allowing oxidative metabolism (55); secrete cytokines, such as IL-12 or IL-18 $(56,57)$; and up-regulate the chemokine receptor CXCR5 to promote homing to the lymphoid B-cell follicle (58) as explored by Mylvaganam et al.. Seemingly, CAR T-cells for HIV applications should be directed against viral proteins to minimize safety concerns and given the lack of reliable biomarkers to identify latently-infected cells. Ergo, CAR T-cells will likely require co-administration with potent latency reactivating agents to promote therapy persistence and reveal cellular targets for clearance. Such combination therapies would benefit from positron emission tomography (PET)-based imaging, as reviewed by Henrich et al., to observe the total-body viral antigen distribution $(59,60)$ and to gain insights concerning the potential for efficacy in difficult to sample tissues $(61,62)$. 


\section{SUMMARY}

Models of cancer and HIV persistence share an interesting paradox: responses promoting self-tolerance when exposed to sustained inflammatory stimuli permit pathological dissemination and escape from immune surveillance. This similarity would suggest common curative approaches via the targeting of immunosuppressive pathways. However, a key distinction is that in cancer the self-immunogen is pervasive; whereas, in ART-treated HIV infection chronic antigenic stimulation arises largely from gut microbial translocation, not from viral proteins. This different in antigen source may represent a key obstacle when translating therapies between cancer and HIV models (63). In designing immunotherapy

\section{REFERENCES}

1. Antiretroviral Therapy Cohort Collaboration. Survival of HIV-positive patients starting antiretroviral therapy between 1996 and 2013: a collaborative analysis of cohort studies. Lancet HIV. (2017) 4:e349-56. doi: 10.1016/S2352-3018(17)30 066-8

2. Siliciano JD, Kajdas J, Finzi D, Quinn TC, Chadwick K, Margolick JB, et al. Long-term follow-up studies confirm the stability of the latent reservoir for HIV-1 in resting CD4+ T cells. Nat Med. (2003) 9:727-8. doi: 10.1038/ nm880

3. Finzi D, Blankson J, Siliciano JD, Margolick JB, Chadwick K, Pierson T, et al. Latent infection of $\mathrm{CD} 4+\mathrm{T}$ cells provides a mechanism for lifelong persistence of HIV-1, even in patients on effective combination therapy. Nat Med. (1999) 5:512-7. doi: 10.1038/8394

4. Chun TW, Davey RTJr, Engel D, Lane HC, Fauci AS. Re-emergence of HIV after stopping therapy. Nature. (1999) 401:874-5. doi: 10.1038/ 44755

5. Davey RTJr, Bhat N, Yoder C, Chun TW, Metcalf JA, Dewar R, et al. HIV-1 and T cell dynamics after interruption of highly active antiretroviral therapy (HAART) in patients with a history of sustained viral suppression. Proc Natl Acad Sci USA. (1999) 96:15109-14. doi: 10.1073/pnas.96.26. 15109

6. Day CL, Kaufmann DE, Kiepiela P, Brown JA, Moodley ES, Reddy S, et al. PD-1 expression on HIV-specific T cells is associated with T-cell exhaustion and disease progression. Nature. (2006) 443:350-4. doi: 10.1038/nature 05115

7. Trautmann L, Janbazian L, Chomont N, Said EA, Gimmig S, Bessette $\mathrm{B}$, et al. Upregulation of PD-1 expression on HIV-specific CD8+ T cells leads to reversible immune dysfunction. Nat Med. (2006) 12:1198202. doi: $10.1038 / \mathrm{nm} 1482$

8. D'Souza M, Fontenot AP, Mack DG, Lozupone C, Dillon S, Meditz A, et al. Programmed death 1 expression on HIV-specific CD4+ $\mathrm{T}$ cells is driven by viral replication and associated with $\mathrm{T}$ cell dysfunction. J Immunol. (2007) 179:1979-87. doi: 10.4049/jimmunol.179.3. 1979

9. Archin NM, Keedy KS, Espeseth A, Dang H, Hazuda DJ, Margolis DM. Expression of latent human immunodeficiency type 1 is induced by novel and selective histone deacetylase inhibitors. AIDS. (2009) 23:1799806. doi: 10.1097/QAD.0b013e32832ec1dc

10. Archin NM, Liberty AL, Kashuba AD, Choudhary SK, Kuruc JD, Crooks $\mathrm{AM}$, et al. Administration of vorinostat disrupts HIV-1 latency in patients on antiretroviral therapy. Nature. (2012) 487:482-5. doi: 10.1038/nature 11286

11. Banga R, Procopio FA, Noto A, Pollakis G, Cavassini M, Ohmiti K, et al. PD-1(+) and follicular helper T cells are responsible for persistent HIV1 transcription in treated aviremic individuals. Nat Med. (2016) 22:75461. doi: $10.1038 / \mathrm{nm} .4113$ strategies, it is also important to consider that adverse event outcomes between these models have substantially different tolerances, as HIV is a manageable chronic disease and cancers are invariably fatal. Future trials will be necessary to determine whether these mechanistic insights regarding escape and exhaustion can be successfully adapted to facilitate long-term, ART-free HIV remission.

\section{AUTHOR CONTRIBUTIONS}

$\mathrm{MP}, \mathrm{KD}, \mathrm{SD}$, and $\mathrm{RA}$ contributed to formulating the theme for this article collection, recruiting authors, and acting as editors for the submissions. MP and JH wrote the editorial, with contributions, and final edits from all authors.

12. Fukazawa Y, Lum R, Okoye AA, Park H, Matsuda K, Bae JY, et al. B cell follicle sanctuary permits persistent productive simian immunodeficiency virus infection in elite controllers. Nat Med. (2015) 21:132-9. doi: 10.1038/nm.3781

13. Connick E, Mattila T, Folkvord JM, Schlichtemeier R, Meditz AL, Ray MG, et al. CTL fail to accumulate at sites of HIV-1 replication in lymphoid tissue. J Immunol. (2007) 178:6975-83. doi: 10.4049/jimmunol.178.11. 6975

14. Chomont N, El-Far M, Ancuta P, Trautmann L, Procopio FA, Yassine-Diab $\mathrm{B}$, et al. HIV reservoir size and persistence are driven by $\mathrm{T}$ cell survival and homeostatic proliferation. Nat Med. (2009) 15:893-900. doi: 10.1038/nm.1972

15. Buzon MJ, Sun H, Li C, Shaw A, Seiss K, Ouyang Z, et al. HIV-1 persistence in CD4+ T cells with stem cell-like properties. Nat Med. (2014) 20:13942. doi: $10.1038 / \mathrm{nm} .3445$

16. Okoye AA, Hansen SG, Vaidya M, Fukazawa Y, Park H, Duell DM, et al. Early antiretroviral therapy limits SIV reservoir establishment to delay or prevent post-treatment viral rebound. Nat Med. (2018) 24:143040. doi: 10.1038/s41591-018-0130-7

17. Colby DJ, Trautmann L, Pinyakorn S, Leyre L, Pagliuzza A, Kroon E, et al. Rapid HIV RNA rebound after antiretroviral treatment interruption in persons durably suppressed in Fiebig I acute HIV infection. Nat Med. (2018) 24:923-6. doi: 10.1038/s41591-018-0026-6

18. Shan L, Deng K, Gao H, Xing S, Capoferri AA, Durand CM, et al. Transcriptional reprogramming during effector-to-memory transition renders $\mathrm{CD} 4(+) \mathrm{T}$ cells permissive for latent hiv-1 infection. Immunity. (2017) 47:766-75.e3. doi: 10.1016/j.immuni.2017.09.014

19. Chetoui N, Boisvert M, Gendron S, Aoudjit F. Interleukin-7 promotes the survival of human CD4+ effector/memory $\mathrm{T}$ cells by up-regulating Bcl2 proteins and activating the JAK/STAT signalling pathway. Immunology. (2010) 130:418-26. doi: 10.1111/j.1365-2567.2009.03244.x

20. Gavegnano C, Brehm JH, Dupuy FP, Talla A, Ribeiro SP, Kulpa DA, et al. Novel mechanisms to inhibit HIV reservoir seeding using Jak inhibitors. PLoS Pathog. (2017) 13:e1006740. doi: 10.1371/journal.ppat.1006740

21. McBrien JB, Mavigner M, Franchitti L, Smith SA, White E, Tharp GK, et al. Robust and persistent reactivation of SIV and HIV by N-803 and depletion of CD8(+) cells. Nature. (2020) 578:154-9. doi: 10.1038/s41586-020-1946-0

22. Cartwright EK, Spicer L, Smith SA, Lee D, Fast R, Paganini S, et al. CD8(+) lymphocytes are required for maintaining viral suppression in SIV-infected macaques treated with short-term antiretroviral therapy. Immunity. (2016) 45:656-68. doi: 10.1016/j.immuni.2016.08.018

23. Collins KL, Chen BK, Kalams SA, Walker BD, Baltimore D. HIV-1 Nef protein protects infected primary cells against killing by cytotoxic T lymphocytes. Nature. (1998) 391:397-401. doi: 10.1038/34929

24. Huang SH, Ren Y, Thomas AS, Chan D, Mueller S, Ward AR, et al. Latent HIV reservoirs exhibit inherent resistance to elimination by CD8+ T cells. J Clin Invest. (2018) 128:876-89. doi: 10.1172/JCI97555

25. Dunn GP, Bruce AT, Ikeda H, Old LJ, Schreiber RD. Cancer immunoediting: from immunosurveillance to tumor escape. Nat Immunol. (2002) 3:9918. doi: $10.1038 /$ ni1102-991 
26. Ren Y, Huang SH, Patel S, Conce Alberto WD, Magat D, Ahimovic DJ, et al. BCL-2 antagonism sensitizes cytotoxic $t$ cell-resistant hiv reservoirs to elimination ex vivo. J Clin Invest. (2020). doi: 10.1172/JCI13 2374

27. Wagner TA, McLaughlin S, Garg K, Cheung CY, Larsen BB, Styrchak $\mathrm{S}$, et al. HIV latency. Proliferation of cells with HIV integrated into cancer genes contributes to persistent infection. Science. (2014) 345:5703. doi: 10.1126/science. 1256304

28. Maldarelli F, Wu X, Su L, Simonetti FR, Shao W, Hill S, et al. HIV latency. Specific HIV integration sites are linked to clonal expansion and persistence of infected cells. Science. (2014) 345:179-83. doi: 10.1126/science.12 54194

29. Funderburg NT, Mehta NN. Lipid abnormalities and inflammation in HIV inflection. Curr HIV/AIDS Rep. (2016) 13:21825. doi: 10.1007/s11904-016-0321-0

30. Lake JE, Currier JS. Metabolic disease in HIV infection. Lancet Infect Dis. (2013) 13:964-75. doi: 10.1016/S1473-3099(13)70271-8

31. Buckley CD, Gilroy DW, Serhan CN. Proresolving lipid mediators and mechanisms in the resolution of acute inflammation. Immunity. (2014) 40:315-27. doi: 10.1016/j.immuni.2014.02.009

32. Herber DL, Cao W, Nefedova Y, Novitskiy SV, Nagaraj S, Tyurin VA, et al. Lipid accumulation and dendritic cell dysfunction in cancer. Nat Med. (2010) 16:880-6. doi: 10.1038/nm.2172

33. Gadola SD, Silk JD, Jeans A, Illarionov PA, Salio M, Besra GS, et al. Impaired selection of invariant natural killer $\mathrm{T}$ cells in diverse mouse models of glycosphingolipid lysosomal storage diseases. J Exp Med. (2006) 203:2293303. doi: 10.1084/jem.20060921

34. Brenchley JM, Price DA, Schacker TW, Asher TE, Silvestri G, Rao S, et al. Microbial translocation is a cause of systemic immune activation in chronic HIV infection. Nat Med. (2006) 12:1365-71. doi: 10.1038/nm1511

35. Schuetz A, Deleage C, Sereti I, Rerknimitr R, Phanuphak N, PhuangNgern Y, et al. Initiation of ART during early acute HIV infection preserves mucosal Th17 function and reverses HIV-related immune activation. PLoS Pathog. (2014) 10:e1004543. doi: 10.1371/journal.ppat.10 04543

36. Vujkovic-Cvijin I, Dunham RM, Iwai S, Maher MC, Albright RG, Broadhurst MJ, et al. Dysbiosis of the gut microbiota is associated with HIV disease progression and tryptophan catabolism. Sci Transl Med. (2013) 5:193ra191. doi: 10.1126/scitranslmed.30 06438

37. Wang Y, Wiesnoski DH, Helmink BA, Gopalakrishnan V, Choi K, DuPont HL, et al. Fecal microbiota transplantation for refractory immune checkpoint inhibitor-associated colitis. Nat Med. (2018) 24:1804-8. doi: 10.1038/s41591-018-0238-9

38. Vetizou M, Pitt JM, Daillere R, Lepage P, Waldschmitt N, Flament C, et al. Anticancer immunotherapy by CTLA-4 blockade relies on the gut microbiota. Science. (2015) 350:1079-84. doi: 10.1126/science.aad1329

39. Gopalakrishnan V, Spencer CN, Nezi L, Reuben A, Andrews MC, Karpinets TV, et al. Gut microbiome modulates response to antiPD-1 immunotherapy in melanoma patients. Science. (2018) 359:97103. doi: $10.1126 /$ science.aan 4236

40. Bailur JK, McCachren SS, Doxie DB, Shrestha M, Pendleton K, Nooka AK, et al. Early alterations in stem-like/resident $\mathrm{T}$ cells, innate and myeloid cells in the bone marrow in preneoplastic gammopathy. JCI Insight. (2019) 5:e127807. doi: 10.1172/jci.insight.127807

41. Deeks SG. HIV: shock and kill. Nature. (2012) 487:43940. doi: $10.1038 / 487439$ a

42. Wightman F, Solomon A, Kumar SS, Urriola N, Gallagher K, Hiener $B$, et al. Effect of ipilimumab on the HIV reservoir in an HIVinfected individual with metastatic melanoma. AIDS. (2015) 29:5046. doi: 10.1097/QAD.0000000000000562

43. Evans VA, van der Sluis RM, Solomon A, Dantanarayana A, McNeil C, Garsia R, et al. Programmed cell death-1 contributes to the establishment and maintenance of HIV-1 latency. AIDS. (2018) 32:1491-7. doi: 10.1097/QAD.0000000000001849

44. Guihot A, Marcelin AG, Massiani MA, Samri A, Soulie C, Autran B, et al. Drastic decrease of the HIV reservoir in a patient treated with nivolumab for lung cancer. Ann Oncol. (2018) 29:517-8. doi: 10.1093/annonc/mdx696
45. Garrido C, Abad-Fernandez M, Tuyishime M, Pollara JJ, Ferrari G, SorianoSarabia N, et al. Interleukin-15-stimulated natural killer cells clear HIV-1infected cells following latency reversal ex vivo. J Virol. (2018) 92:e00235-18. doi: 10.1128/JVI.00235-18

46. Logerot S, Rancez M, Charmeteau-de Muylder B, Figueiredo-Morgado S, Rozlan S, Tambussi G, et al. HIV reservoir dynamics in HAART-treated poor immunological responder patients under IL-7 therapy. AIDS. (2018) 32:715-20. doi: 10.1097/QAD.0000000000001752

47. Ramsuran V, Naranbhai V, Horowitz A, Qi Y, Martin MP, Yuki Y, et al. Elevated HLA-A expression impairs HIV control through inhibition of NKG2A-expressing cells. Science. (2018) 359:86-90. doi: 10.1126/science.aam 8825

48. Lo Monaco E, Tremante E, Cerboni C, Melucci E, Sibilio L, Zingoni A, et al. Human leukocyte antigen E contributes to protect tumor cells from lysis by natural killer cells. Neoplasia. (2011) 13:822-30. doi: 10.1593/neo.1 01684

49. Leibman RS, Richardson MW, Ellebrecht CT, Maldini CR, Glover JA, Secreto AJ, et al. Supraphysiologic control over HIV-1 replication mediated by CD8 T cells expressing a re-engineered CD4-based chimeric antigen receptor. PLoS Pathog. (2017) 13:e1006613. doi: 10.1371/journal.ppat.10 06613

50. Maude SL, Laetsch TW, Buechner J, Rives S, Boyer M, Bittencourt H, et al. Tisagenlecleucel in children and young adults with B-cell lymphoblastic leukemia. N Engl J Med. (2018) 378:439-48. doi: 10.1056/NEJMoa17 09866

51. O’Rourke DM, Nasrallah MP, Desai A, Melenhorst JJ, Mansfield K, Morrissette JJD, et al. A single dose of peripherally infused EGFRvIIIdirected CAR $\mathrm{T}$ cells mediates antigen loss and induces adaptive resistance in patients with recurrent glioblastoma. Sci Transl Med. (2017) 9:eaaa0984. doi: 10.1126/scitranslmed.aaa0984

52. Kinter A, McNally J, Riggin L, Jackson R, Roby G, Fauci AS. Suppression of HIV-specific $\mathrm{T}$ cell activity by lymph node $\mathrm{CD} 25+$ regulatory $\mathrm{T}$ cells from HIV-infected individuals. Proc Natl Acad Sci USA. (2007) 104:33905. doi: 10.1073/pnas.0611423104

53. Weiss L, Donkova-Petrini V, Caccavelli L, Balbo M, Carbonneil C, Levy Y. Human immunodeficiency virus-driven expansion of CD4+CD25+ regulatory $\mathrm{T}$ cells, which suppress HIV-specific CD4 T-cell responses in HIV-infected patients. Blood. (2004) 104:3249-56. doi: 10.1182/blood-2004-01-0365

54. Connick E, Folkvord JM, Lind KT, Rakasz EG, Miles B, Wilson NA, et al. Compartmentalization of simian immunodeficiency virus replication within secondary lymphoid tissues of rhesus macaques is linked to disease stage and inversely related to localization of virus-specific CTL. J Immunol. (2014) 193:5613-25. doi: 10.4049/jimmunol.1401161

55. Kawalekar OU, O'Connor RS, Fraietta JA, Guo L, McGettigan SE, Posey $\mathrm{ADJ}$, et al. Distinct signaling of coreceptors regulates specific metabolism pathways and impacts memory development in CAR T cells. Immunity. (2016) 44:380-90. doi: 10.1016/j.immuni.2016.01.021

56. Yeku OO, Purdon TJ, Koneru M, Spriggs D, Brentjens RJ. Armored CAR T cells enhance antitumor efficacy and overcome the tumor microenvironment. Sci Rep. (2017) 7:10541. doi: 10.1038/s41598-017-10940-8

57. Hu B, Ren J, Luo Y, Keith B, Young RM, Scholler J, et al. Augmentation of antitumor immunity by human and mouse CAR $\mathrm{T}$ cells secreting IL-18. Cell Rep. (2017) 20:3025-33. doi: 10.1016/j.celrep.2017. 09.002

58. Haran KP, Hajduczki A, Pampusch MS, Mwakalundwa G, VargasInchaustegui DA, Rakasz EG, et al. Simian Immunodeficiency Virus (SIV)-specific chimeric antigen receptor-T cells engineered to target B cell follicles and suppress SIV replication. Front Immunol. (2018) 9:492. doi: 10.3389/fimmu.2018.00492

59. Santangelo PJ, Rogers KA, Zurla C, Blanchard EL, Gumber S, Strait K, et al. Whole-body immunoPET reveals active SIV dynamics in viremic and antiretroviral therapy-treated macaques. Nat Methods. (2015) 12:42732. doi: $10.1038 /$ nmeth.3320

60. Santangelo PJ, Cicala C, Byrareddy SN, Ortiz KT, Little D, Lindsay KE, et al. Early treatment of SIV+ macaques with an alpha4beta7 $\mathrm{mAb}$ alters virus distribution and preserves CD4(+) T cells in later stages of infection. Mucosal Immunol. (2018) 11:932-46. doi: 10.1038/mi.2017.112 
61. Lamers SL, Rose R, Maidji E, Agsalda-Garcia M, Nolan DJ, Fogel GB, et al. HIV DNA is frequently present within pathologic tissues evaluated at autopsy from combined antiretroviral therapy-treated patients with undetectable viral loads. J Virol. (2016) 90:8968-83. doi: 10.1128/JVI.00674-16

62. Estes JD, Kityo C, Ssali F, Swainson L, Makamdop KN, Del Prete GQ, et al. Defining total-body AIDS-virus burden with implications for curative strategies. Nat Med. (2017) 23:1271-6. doi: 10.1038/nm.4411

63. Bekerman E, Hesselgesser J, Carr B, Nagel M, Hung M, Wang A, et al. PD-1 blockade and TLR7 activation lack therapeutic benefit in chronic simian immunodeficiency virus-infected macaques on antiretroviral therapy. Antimicrob Agents Chemother. 63:e01163-19. doi: 10.1128/AAC.01163-19
Conflict of Interest: The authors declare that the research was conducted in the absence of any commercial or financial relationships that could be construed as a potential conflict of interest.

Copyright (c) 2020 Paiardini, Dhodapkar, Harper, Deeks and Ahmed. This is an open-access article distributed under the terms of the Creative Commons Attribution License (CC BY). The use, distribution or reproduction in other forums is permitted, provided the original author(s) and the copyright owner(s) are credited and that the original publication in this journal is cited, in accordance with accepted academic practice. No use, distribution or reproduction is permitted which does not comply with these terms. 